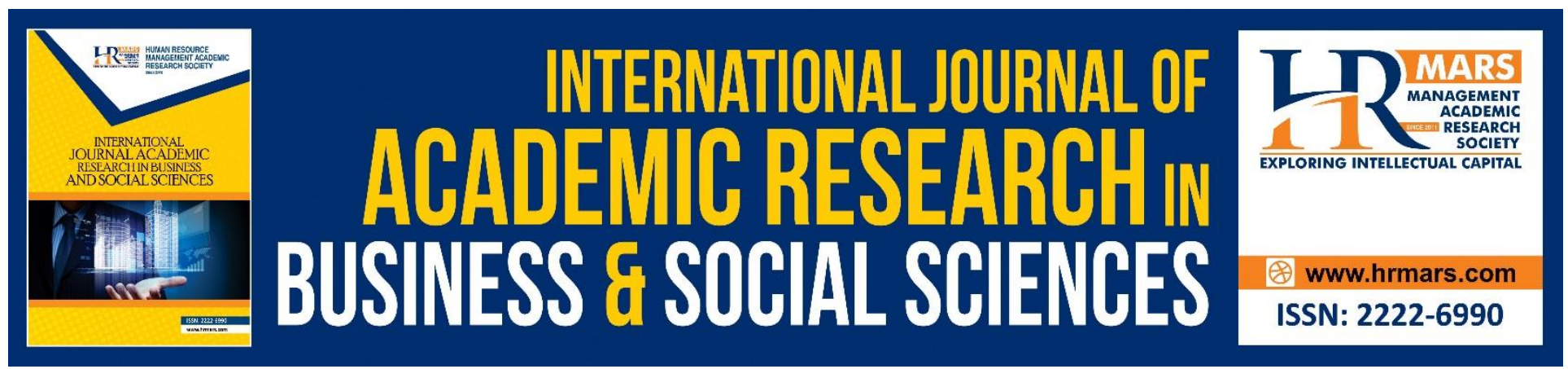

\title{
ASEAN Charter: A Compromise Agreement on Democracy and Human Rights
}

\author{
M. Muttaqien
}

To Link this Article: http://dx.doi.org/10.6007/IJARBSS/v9-i5/5889

DOI: $10.6007 /$ IJARBSS/v9-i5/5889

Received: 24 March 2019, Revised: 04 April 2019, Accepted: 24 April 2019

Published Online: 24 May 2019

In-Text Citation: (Muttaqien, 2019)

To Cite this Article: Muttaqien, M. (2019). ASEAN Charter: A Compromise Agreement on Democracy and Human Rights. International Journal of Academic Research Business and Social Sciences, 9(5), 481-489.

Copyright: (C) 2019 The Author(s)

Published by Human Resource Management Academic Research Society (www.hrmars.com)

This article is published under the Creative Commons Attribution (CC BY 4.0) license. Anyone may reproduce, distribute, translate and create derivative works of this article (for both commercial and non-commercial purposes), subject to full attribution to the original publication and authors. The full terms of this license may be seen at: http://creativecommons.org/licences/by/4.0/legalcode

Vol. 9, No. 5, 2019, Pg. 481 - 489

Full Terms \& Conditions of access and use can be found at http://hrmars.com/index.php/pages/detail/publication-ethics 


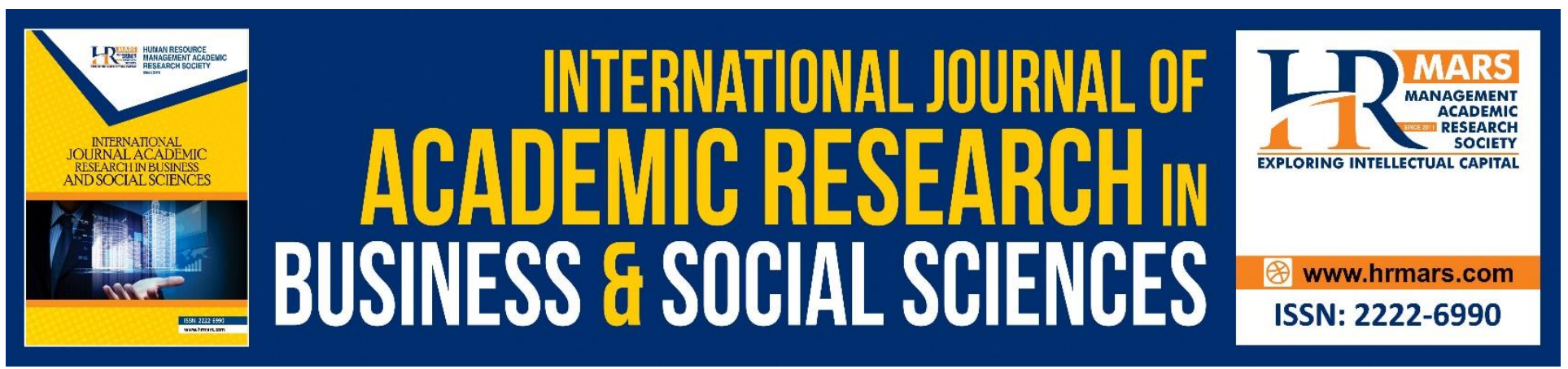

\title{
ASEAN Charter: A Compromise Agreement on Democracy and Human Rights
}

\author{
M. Muttaqien \\ Department of International Relations, Universitas Airlangga, Surabaya-Indonesia
}

\begin{abstract}
This paper tried to examine how diplomacy on democracy and human rights amongst Member States of ASEAN was formulated in the ASEAN Charter. The differences of development and maturity of democracy amongst Member States determined the position of the states in negotiating these issues. By using groups of nation-states as a level of analysis, this study found that on the issues of democracy and human rights which were inserted in the Charter, Member States of ASEAN took a compromise way due to these are sensitive which are close to break non-interference principle. The gradual improvement on human rights promotion and protection has been taken by ASEAN to maintain stability in this region.
\end{abstract}

\section{Introduction}

Historically, ASEAN was an association which involved non-democratic but anti-communist states and was not concerned with the promotion and protection of civil rights. Five original members of ASEAN (Indonesia, Malaysia, Singapore, The Philippines, and Thailand) were then authoritarian regimes. When this association was set up, there was no Charter which bound the Member States. Those five states bound themselves with the ASEAN by signing the Bangkok Declaration on 8 August 1967. This Declaration consisted of the membership of ASEAN, the principles of this association, the aims, course of action, the organization of ASEAN at national and regional levels, and the Secretariat of ASEAN. There was no regulation and orientation of the association to democracy and human rights. This paper tried to examine how diplomacy on democracy and human rights amongst Member States of ASEAN was formulated in the ASEAN Charter.

\section{Methodology}

From five levels of analysis of Morgan (1982) which are individual, groups of individuals, nation-state, groups of nation-states, and international system. This study used the group of nation-states level. It will examine the influences of regional organization (ASEAN) to help explain states' foreign policy behavior as a member of this organization. This level determines how complex influences on decision 
INTERNATIONAL JOURNAL OF ACADEMIC RESEARCH IN BUSINESS AND SOCIAL SCIENCES

Vol. 9, No. 5, May, 2019, E-ISSN: 2222-6990 @ 2019 HRMARS

making will be described, how problems especially on formulating ASEAN Charter amongst Member States are elaborated and the appropriate type of evidence to explore.

Formulation of ASEAN Charter was studied at a group of nation states unit of analysis in which the policies each Member States will be described, explained, and predicted. Democracy and human rights in the framework of ASEAN are used as a unit of explanatory power by which the results will be assessed. The explanatory power of this research will be focused on the role of the states represented by their diplomats in shaping ASEAN Charter: how they interact, build consensus, bargain, negotiate, give supports and put pressure amongst Member States.

\section{Results/Discussion}

\section{Non-Interference versus Protecting Civil Rights}

The principle of non-interference was respected amongst ASEAN Member States due to the establishment of ASEAN was based on the historical experience of the Member States in which was close to conflict. The relationship between Indonesia and Malaysia, for instance, was sensitive with regard to intervention and sovereignty issues due to the experience of several rebellions, which had involved external powers. Indonesia accused Malaysia of being involved in the PRRI/Permesta rebellions in the period 1957-1958 as well as Malaysia accusing Indonesia of having been involved in the Brunei revolts in 1963 (Mackie, 1974). Other countries in Southeast Asia had these kinds of problems, such as the relationship between Thailand and Malaysia on the rebellion of the Muslim Malays in Southern Thailand.

Besides non-interference, the so-called ASEAN Way as a mechanism for making decisions had been implemented since the establishment of the Association. This ASEAN Way was a set of working guidelines, which set out the procedure by which conflicts will be managed by the Association. It emphasized a conflict resolution based on trust, consultation and agreement rather than hard negotiation, bargaining, and taking and giving of results (Goh, 2003).

To expand democracy and human rights in ASEAN, there are difficult challenges. Since being formed in Bangkok on 8 August 1967, ASEAN did not have a constitution to tie its members. This association, as stated by former Minister of Indonesian Foreign Affairs Ali Alatas (Sukarjaputra, 2006), was not acknowledged by the UN as an observer in the UN due to the absence of a legal identity (Sukma, 2008). Then, he added, although ASEAN succeeded in formulating several treaties, there was no regulation on sanctions if its members disobeyed the treaties. As mentioned previously, conflict amongst its members were settled through a mechanism known as the ASEAN Way. The importance of a clear legal status for ASEAN was apparent to the ten ASEAN Leaders at the 11th ASEAN Summit in Kuala Lumpur (12-14 December 2005). At this Summit they agreed to draft a constitution known as ASEAN Charter (ASEAN Secretariat, 2005).

Formulation of the Charter was not easy because it had to accommodate ten ASEAN countries with different interests and different domestic political situations. Since the success of the general elections of 1999 and 2004, Indonesia had been recognized as having democratic credentials in 
INTERNATIONAL JOURNAL OF ACADEMIC RESEARCH IN BUSINESS AND SOCIAL SCIENCES Vol. 9, No. 5, May, 2019, E-ISSN: 2222-6990 @ 2019 HRMARS

Southeast Asia. The Philippines and Thailand had been transformed into democracies earlier but still faced the threat of coups from the military. The two other founding Member States, Malaysia and Singapore were known as quasi-democracies due to their governments restricting opposition activities. Brunei Darussalam, which became the sixth Member of ASEAN in 1984 immediately it had gained its independence from Britain, was an Islamic monarchy in which power was centralized to the Sultan. The subsequent new Member States Vietnam (1995), Laos (1997), and Myanmar (1997) were categorized as authoritarian regimes, while Cambodia (1999) was a hybrid regime. On the one hand, the old members of ASEAN such as Indonesia, Thailand, Malaysia, the Philippines, Singapore, and Brunei wanted a new ASEAN that was more open and more dynamic. On the other hand, the new member states such as Vietnam, Laos, Myanmar and Cambodia wanted to maintain the status quo (Pattiradjawane, 2009).

\section{Debating on the Formulation of ASEAN Charter}

Crucial debates on the content of the Charter were on the certain points of the purposes, the principles, and the decision-making process. With regard to the purposes of the ASEAN, the debate was between whether the Association was only to promote democracy and human rights or was also to strengthen democracy, promote and protect human rights. Regarding this, Indonesia formulated the maximum target to include in the ASEAN Charter the promotion and protection of democracy and civil rights. This ultimate goal had to be negotiated with the other Member States. This goal was derived from domestic stakeholders'inputs that had been collected by the Ministry of Foreign Affairs of Indonesia from several seminars and workshops, interactions with civil societies, international experts from campuses, and politicians. Dian Triansyah Djani, a senior Indonesian diplomat and a member of the HLTF maintains, “...there were several important issues/elements that were continuously pursued and championed by the Indonesian negotiator to be included in the ASEAN Charter, in order for the Charter to be 'sale-able' to the Indonesian public. Among these, the principle of democracy, good governance, fundamental freedoms, rule of law and constitutional government as well as promotion and protection of human rights, were imperative" (Djani, 2009).

In terms of the principles of ASEAN, the main debate was about the principle of this Association rejecting the changing of regimes within ASEAN member states through non-democratic constitutional mechanisms (Article 2 point h) (ASEAN Secretariat, http://www.aseansec.org/ACUpdate.pdf). Neither Myanmar (with its military Junta) and Laos (with its People's Revolutionary Party), where the governments had come to power by ignoring or overthrowing democratic institutions, were satisfied with this principle; however, due to strong pressures from the other ASEAN countries, finally both accepted it. Then, when it came to the principle of non-interference, the EPG proposed that the non-interference principle could not be implemented if the Member States of ASEAN broke the agreement, especially in the protection of human rights (Luhulima, 2008). Indonesia suggested a mechanism by which it was possible for ASEAN to get involved in helping any member country solve its internal conflict or more specifically in the protection of human rights amongst ASEAN Member States (Djani, 2009), but this proposal was rejected by most of the other Member States. Finally, non-interference had been maintained as a principle of the Association without exception. 
Another debate was about the decision-making process. Even though the EPG had recommended to the Task Force that the organization consider "...an alternative and flexible decision-making mechanism" (Manalo, 2009), which meant including voting and not just consensus, the final text of the Charter Article 20 verse 1 stated that the basic principle of decision making in ASEAN would be based on consultation and consensus (musyawarah dan mufakat) (ASEAN Secretariat, http://www.aseansec.org/AC-Update.pdf.). Voting was not clearly stated in the Charter. Even the proposal to include an 'ASEAN minus X' formula was not accommodated by the Charter (Kraft, 2008). In other words, the 'ASEAN Way' had been maintained as the mechanism for making decisions (Alatas, 2008). However, to accommodate the recommendation of EPG, article 20 verse 2 stated, "Where consensus cannot be achieved, the ASEAN Summit may decide how a specific decision can be made" (ASEAN Secretariat, http://www.aseansec.org/AC-Update.pdf.). A member of Commission I of the DPR, Marzuki Darusman, criticized this mechanism because a consultation and consensus mechanism made the decision long-winded and long drawn-out and a decision already made by majority of ASEAN member states could be inhibited by one or two states (Politika, 2008).

After being signed by the ten ASEAN leaders in Singapore on 20 November 2007, two years after the 11th ASEAN Summit, the ASEAN Charter had to be ratified by each parliament. Indonesia was the last country, together with Thailand, to do this. This was as a consequence of the dynamics of domestic politics in the country where democracy was still evolving. During nine months from early 2008 Foreign Ministry of Indonesia had campaigned massively to domestic stakeholders to publicize the Charter such as visiting and discussing with media editors, giving lectures at 38 universities, 67 schools, and 10 pesantrens, organizing 14 seminars and workshops, and conducting 23 dialogues with various members of organizations including NGOs, businessmen, and political parties. Almost 200 activities were undertaken in different parts of Indonesia during these nine months (Djani, 2009).

Before ratifying the Charter, Commission I of the DPR, as a partner of the executive on foreign affairs looked for advisory inputs with regard to the Charter by inviting experts from think-tanks and campuses and a member of the EPG Ali Alatas. Commission I also conducted a preliminary hearing with the government, represented by a member of HLTF, to present the government's views on 18 February 2008. Then, officially the Charter was presented by Foreign Minister Nur Hassan Wirajuda in front of Commission I on 9 September 2008 (Djani, 2009). Finally, a majority of the parties in the Indonesian parliament agreed to ratify the Charter; however, they criticized several items of the Charter. In the general views of the parties in the parliament, there were at least five issues that had to be considered further by the government: (1) the mechanism of the decision making process in ASEAN would be not effective if it was only based on consultation and consensus; (2) the plan to establish the ASEAN Human Rights Body had to be followed up by the government; (3) the sanctions against ASEAN member states if they break the Charter were not clear enough to be regulated; (4) the involvement of the public in ASEAN was not clearly regulated; (5) the protection of migrant worker; and (6) the contribution of the Charter's ratification to Indonesian national interests (Alatas, 2008). 
INTERNATIONAL JOURNAL OF ACADEMIC RESEARCH IN BUSINESS AND SOCIAL SCIENCES Vol. 9, No. 5, May, 2019, E-ISSN: 2222-6990 ㄷ 2019 HRMARS

\section{The ASEAN Human Rights Body: Gradual Improvement}

When it came to the implementation of the Charter, the crucial problem was the establishment of the ASEAN Human Rights Body as mentioned in Article 14 verse 1: "In conformity with the purposes and principles of the ASEAN Charter relating to the promotion and protecting of human rights and fundamental freedoms, ASEAN shall establish an ASEAN Human Rights Body" (ASEAN Secretariat, http://www.aseansec.org/AC-Update.pdf.). The formulation of this article was the most sensitive, controversial, and difficult to be undertaken among the ASEAN Member States (Putra, 2009). The ten members of the HTLF when they formulated this article were divided into three groups: (i) Cambodia, Laos, Myanmar and Vietnam which rejected the establishment of an ASEAN Human Rights Body; (ii) Indonesia and Thailand which fully supported it, and (iii) Brunei, Malaysia, the Philippines and Singapore which took a middle position (Manalo, 2009). Even though finally all ten member states agreed to include the establishment of this body in the ASEAN Charter, they did not have similar points of view with regard to the roles and authorities of this body in promoting and protecting human rights amongst ASEAN states. The problem arose because of the different domestic situation in each member state regarding human rights enforcement. For instance, among the ten, National Human Rights Commissions existed in only four: Indonesia, Thailand, Malaysia, and The Philippines (Djani, 2009).

In terms of the establishment of the ASEAN Human Rights Body, officially the name of the body was the ASEAN Intergovernmental Commission on Human Rights (AICHR), and eight meetings had been conducted by a High Level Panel (HLP) since July 2008 to draft the Commissions 'OR (Terms of Reference). Indonesia proposed the TOR balance between the promotion and the protection of human rights. The consequences of this proposal were that the body has authorities to evaluate, monitor, make reports, investigate, and take an action to solve human rights violations among ASEAN member states. The body had to be independent and involve government as well as non-government representatives (Media Indonesia, 2008). However, this proposal was rejected by a majority of the members of ASEAN.

The rejection was due to the principles of the ASEAN (Article 2 verse 2 point e and $f$ ) which state, "...non-interference in the internal affairs of ASEAN Member States and respect for the right of every Member State to lead its national existence free from external interference, subversion and coercion" (ASEAN Secretariat, http://www.aseansec.org/AC-Update.pdf). Myanmar and Cambodia, which had been previously criticized and targeted with sanctions by the international community because of human rights violations, strongly opposed Indonesia's proposal of the human rights body. Meanwhile, regarding the decision-making mechanism, the basic principle of decision-making process of ASEAN was consultation and consensus (Article 20).

A strong push by the Indonesian Foreign Minister to his counterparts at the 42nd ASEAN Ministerial Meeting (AMM) in Phuket, Thailand nearly stopped the establishment of the body. Hassan Wirajuda criticized the draft of the TOR, because the ASEAN standard for its proposed human rights body was far under that of other international human rights organizations such as in the UN, European Union, Organization of American States (OAS), and Organization of African Union (OAU). It was also below the new Indonesian national standard (Sukarjaputra, 2009). Wirajuda added that the framework for 
the establishment of the body emphasized promotion and not protection of human rights (Jakarta Globe, 2009). Due to the establishment of the body nearly being scuttled, Indonesia had to reduce its negotiation target with regard to human rights protection in Southeast Asia, especially in monitoring and punishing member nations which violated human rights, but with a guarantee that the TOR would be signed by all Member States of ASEAN (Casey, 2009).

Criticisms of the establishment of the AICHR rose among human rights activists as well as international organizations, such as the UN High Commissioner for Human Rights and Amnesty International (Evans, R., 2009). The critics emerged because there was no article regulating sanction against a member state which commits massive human rights violations. Different from other regional organizations in Europe (EU), Africa (OAU) and America (OAS) which established human rights courts, the AICHR did not create an ASEAN Court for Human Rights. The absence of the human rights court in ASEAN indicated that the protection of human rights in this region was not legally binding. Also, the involvement of civil society groups concerned with social justice and human rights was not accommodated by the Commission. The consequence of the AICHR's weak TOR was that ASEAN could not be an effective institution to force any its members who were oppressive against its people and violate human rights, such as in Myanmar (Lawansiri, 2009). In other words, the Commission had no clear mandate to protect victims of human rights abuses in the region.

However, some opinions, especially from government representatives of ASEAN, argued that the formation of AICHR was the best that ASEAN could do to improve human rights promotion and protection in this region. It was an evolutionary process and a major achievement of ASEAN with regards to human rights improvement. Moreover, talking about human rights in the Association had been sensitive issue ever since ASEAN had existed. Abhisit Vejjajiva, ASEAN Leader and Thailand Prime Minister said, "It's better to make a start than to leave it hanging, with no progress at all" (Casey, 2009). Termsak Chalermpalanupap, a Singaporean diplomat and Special Assistant to the Secretary-General of ASEAN, responding to critics when the AICHR was still in the process of being formulated, stated:

"The establishment of the ASEAN Human Rights Body (AHRB) is not an end in itself; it is merely the new beginning. After its launch, the most important added value of the AHRB is in providing a new venue and a new learning process for diverse ASEAN Member States to cooperate on human rights at the regional level. In so doing, the AHRB is expected to develop and gradually take on new and more difficult functions, including various aspects of human rights protection" (Chalermpalanupap, 2009).

Indonesia's position on the consensus about the establishment of the AICHR was one of disappointment, even though Indonesia's Foreign Minister had eventually approved the TOR of the AICHR. Although this TOR did more to promote rather than protect human rights in the region, Indonesia compromised after the other Member States agreed to give a guarantee that the TOR would be reviewed every five years. This guarantee was passed after Indonesia's Foreign Minister Hassan Wirajuda threatened to resign from the consensus if it was rejected by the other Member 
States. To strengthen this official commitment, he further demanded that the guarantee had to be declared by the Heads of State/Government of the Member States of the ASEAN at the 15th ASEAN Summit in Thailand in October 2009, not just by their foreign affairs ministers (Kompas, 2009). Finally, the strong force of Indonesia was accepted by other Member States and at that ASEAN Summit the Cha-Am Hua Hin Declaration on the Intergovernmental Commission on Human Rights included the statement that the governments:

"Recognize that the TOR of the AICHR shall be reviewed every five years after its entry into force to strengthen the mandate and functions of the AICHR in order to further develop mechanisms on both the protection and promotion of human rights. This review and subsequent reviews shall be undertaken by the ASEAN Foreign Ministers Meeting" (ASEAN Secretariat, 2009).

\section{Conclusion}

The decision making process of state's foreign policy is based on the assumption that the state as a social organization exists in two environments: its domestic and international environments. Both have become increasingly interrelated. The formulation of the ASEAN Charter is understanding impact of domestic politics amongst Member States on the regional diplomacy as important as understanding the impacts of international politics on the formulation of foreign policy. It is believed that foreign policy is a reflection of domestic political reality. With variety domestic political systems amongst the Member States, ASEAN Charter is a compromise agreement on the issues of democracy and human rights due to these are sensitive which are close to break non-interference principle.

\section{Corresponding Author}

M. Muttaqien, Department of International Relations, Universitas Airlangga, Surabaya-Indonesia. Email: m.muttaqien@fisip.unair.ac.id

\section{References}

Alatas, A. (2008). The ASEAN charter: towards its ratification and implementation. Jurnal Luar Negeri, 25(2), 58-63.

ASEAN Secretariat (2005). Chairman's statement of the 11th ASEAN summit one vision, one identity, and one community, Kuala Lumpur 12 December 2005. Retrieved from http://www.aseansec.org/18039.htm

ASEAN Secretariat (n.d). The ratification of the ASEAN charter. Retrieved from http://www.aseansec.org/AC- Update.pdf.

ASEAN Secretariat (2009). Cha-Am Hua Hin declaration on the intergovernmental commission on human rights. Retrieved from www.aseansec.org/documents/declaration-AICHR.pdf

Casey, M. (2009). Southeast asia approves human rights body. The Jakarta Post, 21 July.

Chalermpalanupap, T. (2009). 10 facts about ASEAN human rights cooperation. ASEAN Secretariat. Retrieved from www.aseansec.org/HLP-OtherDoc-1.pdf

Djani, D.T. (2009). A long journey. In the making of the ASEAN charter, Eds., Koh, T, et al, Singapore: World Scientific Publishing Co, Pte. Ltd., 137-50.

Evans, R. (2009). UN official disappointed on new ASEAN body. The Jakarta Post, 24 July. 
INTERNATIONAL JOURNAL OF ACADEMIC RESEARCH IN BUSINESS AND SOCIAL SCIENCES

Vol. 9, No. 5, May, 2019, E-ISSN: 2222-6990 @ 2019 HRMARS

Goh, G. (2003). The ASEAN way: non-intervention and ASEAN's role in conflict management.

Stanford Journal of East Asian Affairs, 3 (1), 113-8, Retrieved from

http://www.stanford.edu/group/sjeaa/journal3/geasia1.pdf.

Jakarta Globe (2009). Indonesia seeks more Powers for ASEAN's human rights body. 21 July.

Kraft, H. J. S. (2008). A charter for ASEAN: challenges and prospects for community building. The Indonesian Quarterly, 36(3-4), 275-95.

Kompas (2009). 9 August.

Lawansiri, P. (2009). Human rights: a struggle going nowhere. The Jakarta Post, 24 July.

Luhulima, C. P. F. et al (2008). Masyarakat Asia Tenggara menuju komunitas ASEAN 2015. Yogyakarta: IPI-Pustaka Pelajar.

Mackie, J. A. C. (1974). Konfrontasi: the Indonesia-Malaysia dispute 1963-1966. London-New YorkMelbourne: Oxford University Press.

Manalo, R. G. (2009). Drafting ASEAN's tomorrow: the eminent persons group and the ASEAN charter. In the making of the ASEAN charter, Eds., Koh, T., et al, Singapore: World Scientific Publishing Co, Pte. Ltd., 37-45.

Media Indonesia (2008). Pembentukan Badan HAM ASEAN Tersendat. 27 March

Morgan, P. (1982). Theories and Approaches to International Politics. Transaction.

Pattiradjawane, R. (2009). Membangun ASEAN Baru. Kompas, 15 July 2009.

Politika (2008). 23 October.

Putra, P.D.P.O. (2009). Heart labour. In the making of the ASEAN charter, Eds., Koh, T., et al, Singapore: World Scientific Publishing Co, Pte. Ltd., 1-15.

Sekretariat Jenderal DPR-RI (2008). Pemandangan mini fraksi-fraksi terhadap RUU tentang pengesahan charter of the association of Southeast Asian nations. Sekretariat Jenderal DPRRI.

Sukarjaputra, R. (2006). Piagam ASEAN: bola liar masa depan ASEAN. Kompas, 9 April 2006.

Sukarjaputra, R. (2009). Badan HAM ASEAN jauh di bawah standar. Kompas, 9 August.

Sukma, R. (2008). Building the ASEAN community: how useful is the ASEAN charter. The Indonesian Quarterly, Special Issue, 36 (3-4), 258-77 